\title{
Zebrafish genetics gets the Scube on Hedgehog secretion
}

\author{
Philip W. Ingham ${ }^{1}$ \\ Institute of Molecular and Cell Biology (IMCB), Singapore 138673, Singapore
}

\begin{abstract}
Inspired by a zebrafish mutation, two recent studies by Creanga and colleagues (pp. 1312-1325) and Tukachinsky and colleagues have shed new light on the way in which lipidated Hedgehog proteins are secreted and released from expressing cells, suggesting a model for the sequential action of the Disp and Scube 2 proteins in this process.
\end{abstract}

In this era of transcriptomes, proteomes, and interactomes, it is all too easy to lose sight of the surgical precision that forward genetics brings to biological analysis. Two recent studies from Creanga et al. (2012) and Tukachinsky et al. (2012) provide a timely reminder of the important insights that can flow from the pursuit of molecules identified through phenotypic screens. The 1996 Tübingen screen was the first systematic attempt to identify vertebrate developmental genes using zebrafish as a model. Among the variety of mutant classes defined on the basis of shared phenotypes, the "you" class (van Eeden et al. 1996) has proven to be a rich source of mutations in Hedgehog (Hh) signaling pathway components. So called because of the U-shaped somites that form in the absence of a specialized group of muscle cells that are induced by Hh signaling, the genetic mapping and positional cloning of these genes have revealed that most of the mutations inactivate well-known Hh pathway proteins. The one exception to this rule has been the eponymous you mutation; the independent cloning of you by three different groups (Kawakami et al. 2005; Woods and Talbot 2005; Hollway et al. 2006) revealed it to disrupt the gene encoding Scube2-a member of the signal sequence, cubulin domain, epidermal growth factor-related (Scube) family previously characterized in mice (Grimmond et al. 2001)_but with no known role in Hh signaling. Despite initial speculation that Scube2 might be involved in receptor-mediated endocytosis of Sonic Hedgehog (Shh) (Hollway et al. 2006) or even that it might modulate Hh activity indirectly through an interaction with bone morphogenetic proteins (BMPs) (Kawakami et al. 2005), careful biochemical characterization has now revealed it to be essential for the efficient release of Hh from secreting cells.

[Keywords: DispatchedA; Hedgehog; Scube2; morphogen release; palmitate] ${ }^{1}$ Correspondence

E-mail pingham@imcb.a-star.edu.sg

Article is online at http://www.genesdev.org/cgi/doi/10.1101/gad.207126.112.
Among the several mysteries surrounding Hh signaling, the dual lipidation of Hh proteins has been, perhaps, the most perplexing. How can a protein act across multiple cell diameters if its post-translational modification promotes its retention in the membrane of the cells that produce it? When first discovered, this property did not seem so problematic: After all, the best-known role of $\mathrm{Hh}$ in the Drosophila embryo was to mediate interactions between immediately adjacent cells at the parasegment boundary (Ingham 1993). But as successive studies uncovered long-range influences of $\mathrm{Hh}$ proteins in both vertebrates and flies, the conundrum became inescapable, and the subsequent discovery that Hh proteins are also palmitylated at their $\mathrm{N}$ termini (Pepinsky et al. 1998) only deepened the mystery.

Although initial studies in Drosophila reinforced the notion that cholesterol limits the spread of $\mathrm{Hh}$ from its source (Burke et al. 1999), analysis of its effect on the distribution of the vertebrate homolog Shh pointed to the opposite conclusion: Instead of preventing ligand release, it seemed that the cholesterol moiety is crucial for efficient dispersal of Shh across the limb bud (Lewis et al. 2001), apparently by promoting the formation of multimeric complexes that allow the protein to evade association with the membrane (Zeng et al. 2001). In line with this, a careful re-examination of the effects of $\mathrm{Hh}$ lipidation in Drosophila imaginal discs suggested that the long-range activity and multimerization of insect $\mathrm{Hh}$ is also cholesterol dependent (Gallet et al. 2006).

Genetic analysis in Drosophila revealed one clue: the aptly named Dispatched (Disp) protein. Flies mutant for dispatched exhibit an inability to release the Hh protein from producing cells, resulting in a Hh-like phenotype (Burke et al. 1999). Notably, the Disp protein shares significant structural homology with the Hh receptor Patched (Ptc), including the so-called sterol-sensing domain (SSD), a motif characteristic of a variety of proteins involved in lipid metabolism, among which is the SREBP (sterol regulatory element-binding protein) cleavage-activating protein (SCAP). While possession of an SSD seemed suggestive of Disp interacting directly with cholesterolmodified $\mathrm{Hh}$, there has been, to date, no direct proof of such an interaction.

Now, through a series of elegant biochemical experiments, Tukachinsky et al. (2012) have accumulated compelling evidence that cholesterol does indeed mediate an 
interaction between $\mathrm{Hh}$ proteins and Disp, an interaction that appears essential for secretion of the ligand. Key to their analysis was the use of photoreactive cholesterol derivatives that allowed efficient cross-linking of lipidated Shh to DispA (the vertebrate counterpart of Drosophila Disp), thereby circumventing the potential disruption of any interaction during detergent extraction of the proteins from the plasma membrane. Modification of Shh with these cholesterol derivatives was achieved by depleting 293T cells of endogenous sterols and adding back 25-azicholesterol or 6-azicholestanol to the culture medium. To address whether this interaction is necessary for Shh secretion, the investigators deleted part of the first extracellular loop of DispA on the basis that the analogous region of Ptc is required for Hh binding, while the same domain of SCAP mediates its interaction with cholesterol. Cells expressing such a mutant form of DispA failed to secrete the lipidated Shh, which in turn could not be cross-linked to the mutant protein.

Although not conclusive, these findings certainly provide strong support for the notion that interaction with Disp is necessary for secretion of lipidated Hh. Yet while this is likely to be the case, Tukachinsky et al. (2012) also showed that such an interaction is not sufficient for Shh release. At first glance, this seems consistent with the proposal of Ohlig et al. (2011) that Shh release is mediated by the metalloprotease ADAM19. According to this model, Shh multimers remain tethered to the cell surface in an inactive conformation via their palmityl (rather than their cholesterol moieties) and are only released following cleavage of the palmitylated $\mathrm{N}$-terminal peptide by ADAM19. In addition, removal of the peptide is proposed to be necessary not only to release the ligand, but also to relieve it from an intermolecular inhibition mediated by the cleaved peptide sequences. While consistent with the structural properties of the Hh protein, this finding would appear at odds with previous studies indicating that Hh activity is potentiated by its palmitylation (Pepinsky et al. 1998). Moreover, Tukachinsky et al. (2012) found that in serum-free medium, DispA-expressing cells fail to release cholesterol-modified Shh, irrespective of whether it is palmitylated. Based on this and other lines of evidence, they concluded that it is the cholesterol rather than the palmityl adduct that mediates membrane retention of Shh; thus, to release lipidated Shh, the affinity of cholesterol for the membrane must be overcome somehow.

How is this accomplished? An answer to this question has now emerged through analysis of the function of the Scube2 protein, which was first implicated in Hh signaling by the zebrafish you mutation. Using a combination of genetic mosaic and epistasis analysis, Woods and Talbot (2005) had originally argued that Scube2 acts in a nonautonomous fashion to potentiate the Hh signal upstream of its receptor Ptc, possibly by mediating its stability or transport. Taking this suggestion as their cue, Creanga et al. (2012) and Tukachinsky et al. (2012) asked whether the Scube2 protein might act to facilitate the release of $\mathrm{Hh}$. By coexpressing the proteins in HEK293 cells, they found that Scube2 does indeed dramatically increase the levels of Shh released into the culture medium. Crucially, the same effect could be elicited by adding soluble Scube2 to the medium of cells expressing only Shh, consistent with its acting to release Shh from the cell surface rather than enhancing its synthesis or processing. Notably, Scube2 also enhanced the release of nonpalmitylated Shh but made no difference to the release of non-cholesterol-modified Shh, indicating that it acts specifically to disrupt cholesterol-mediated membrane anchoring. Consistent with this, Tukachinsky et al. (2012) also found that Scube2 can release a cholesterolmodified form of an unrelated protein (Halotag) from the surface of expressing cells and showed that the cholesterol moiety is both necessary and sufficient to mediate physical interaction between Shh and Scube2. However, Creanga et al. (2012) also found that while the palmityl adduct is not necessary for Scube2-mediated release, it enhances the physical interaction between the two proteins and enhances the rate of release from expressing cells.

Taken together, these new findings provide an elegant solution to the long-standing puzzle of how lipid-modified Hh is released from cells: They suggest a "hand-off model" whereby Hh first traverses the lipid bilayer via its interaction with Disp and then is extracted from the membrane via its interaction with Scube2. Exactly how Scube2 facilitates the subsequent movement of Hh away from its source remains unclear: One possibility is that it acts as a chaperone that allows the assembly of $\mathrm{Hh}$ into multimeric units; alternatively, $\mathrm{Hh}$ may remain complexed with Scube2, which may also promote the ligandreceptor interaction, perhaps by binding directly to Ptc or the coreceptors Cdo and Boc, as suggested by Tukachinsky et al. (2012).

Given the apparently essential role of Scube2 in Hh release in HEK293 cells, it is notable that Drosophila lacks a Scube2 gene and that the zebrafish you mutant phenotype is the weakest of its class. An explanation for the latter has been provided in a recent study by Johnson et al. (2012), which showed that three Scube genes in zebrafish act in a partially redundant manner to mediate Hh signaling. The former issue is more of a puzzle: As Tukachinsky et al. (2012) pointed out, it may well be that the well-characterized interaction between lipophorin and $\mathrm{Hh}$ in Drosophila serves the same purpose as the Scube2 interaction with vertebrate Hh proteins. But as they also observed, there is no evidence of widespread lipophorin distribution in the embryo, a fact that may explain the largely short-range mode of Hh signaling in the Drosophila embryo.

These recent studies illustrate how the identification of genes controlling developmental processes can prove incisive in unraveling complex cell-biological processes that might otherwise resist biochemical analysis. Whether Scube2 will turn out to be one of the dwindling number of nuggets at the end of a gold rush remains to be seen. Like the other members of its class, the you mutant through which Scube2 was implicated in Hh signaling acts zygotically. The breakthrough in dissecting signaling pathways using Drosophila genetics came with the 
development of techniques for identifying genes that are expressed maternally as well as zygotically (St Johnston 2002). Such genes represent an untapped resource in zebrafish, and until methods for their systematic identification are established, the potential of this organism for identifying critical components of biochemical pathways will remain only partially realized.

\section{References}

Burke R, Nellen D, Bellotto M, Hafen E, Senti KA, Dickson BJ, Basler K. 1999. Dispatched, a novel sterol-sensing domain protein dedicated to the release of cholesterol-modified hedgehog from signaling cells. Cell 99: 803-815.

Creanga A, Glenn TD, Mann RK, Saunders AM, Talbot WS, Beachy PA. 2012. Scube/You activity mediates release of dually lipid-modified Hedgehog signal in soluble form. Genes Dev 26: 1312-1325.

Gallet A, Ruel L, Staccini-Lavenant L, Thérond PP. 2006. Cholesterol modification is necessary for controlled planar long-range activity of Hedgehog in Drosophila epithelia. Development 133: 407-418.

Grimmond S, Larder R, Van Hateren N, Siggers P, Morse S, Hacker T, Arkell R, Greenfield A. 2001. Expression of a novel mammalian epidermal growth factor-related gene during mouse neural development. Mech Dev 102: 209211.

Hollway GE, Maule J, Gautier P, Evans TM, Keenan DG, Lohs C, Fischer D, Wicking C, Currie PD. 2006. Scube mediates Hedgehog signalling in the zebrafish embryo. Dev Biol 294: 104-118.

Ingham PW. 1993. Localized hedgehog activity controls spatial limits of wingless transcription in the Drosophila embryo. Nature 366: 560-562.

Johnson JL, Hall TE, Dyson JM, Sonntag C, Ayers K, Berger S, Gautier P, Mitchell C, Hollway GE, Currie PD. 2012. Scube activity is necessary for Hedgehog signal transduction in vivo. Dev Biol 368: 193-202.

Kawakami A, Nojima Y, Toyoda A, Takahoko M, Satoh M, Tanaka H, Wada H, Masai I, Terasaki H, Sakaki Y, et al. 2005. The zebrafish-secreted matrix protein you/Scube is implicated in long-range regulation of hedgehog signaling. Curr Biol 15: 480-488.

Lewis PM, Dunn MP, McMahon JA, Logan M, Martin JF, StJacques B, McMahon AP. 2001. Cholesterol modification of sonic hedgehog is required for long-range signaling activity and effective modulation of signaling by Ptc1. Cell 105: 599-612.

Ohlig S, Farshi P, Pickhinke U, van den Boom J, Höing S, Jakuschev S, Hoffmann D, Dreier R, Schöler HR, Dierker T, et al. 2011. Sonic hedgehog shedding results in functional activation of the solubilized protein. Dev Cell 20: 764-774.

Pepinsky RB, Zeng C, Wen D, Rayhorn P, Baker DP, Williams KP, Bixler SA, Ambrose CM, Garber EA, Miatkowski K, et al. 1998. Identification of a palmitic acid-modified form of human Sonic hedgehog. I Biol Chem 273: 1403714045.

St Johnston D. 2002. The art and design of genetic screens: Drosophila melanogaster. Nat Rev Genet 3: 176-188.

Tukachinsky H, Kuzmickas RP, Jao CY, Liu J, Salic A. 2012. Dispatched and scube mediate the efficient secretion of the cholesterol-modified hedgehog ligand. Cell Rep. 2: 308-320.

van Eeden FJ, Granato M, Schach U, Brand M, Furutani-Seiki M, Haffter P, Hammerschmidt M, Heisenberg CP, Jiang YJ, Kane
DA, et al. 1996. Mutations affecting somite formation and patterning in the zebrafish, Danio rerio. Development 123: 153-164.

Woods IG, Talbot WS. 2005. The you gene encodes an EGF-CUB protein essential for Hedgehog signaling in zebrafish. PLoS Biol 3: e66. doi: 10.1371/journal.pbio.0030066.

Zeng X, Goetz JA, Suber LM, Scott WJ Jr, Schreiner CM, Robbins DJ. 2001. A freely diffusible form of Sonic hedgehog mediates long-range signalling. Nature 411: 716720 . 


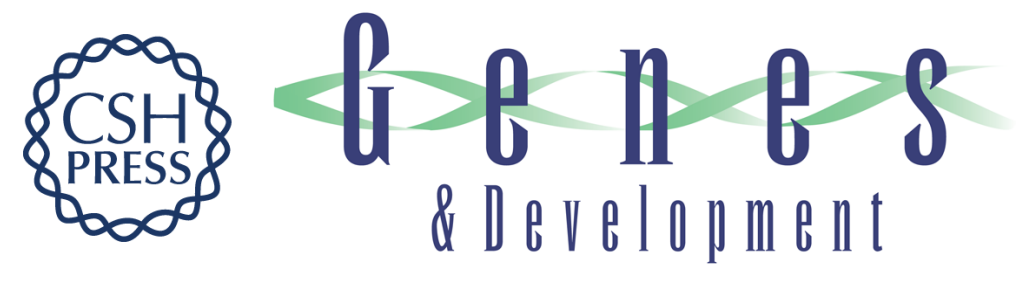

\section{Zebrafish genetics gets the Scube on Hedgehog secretion}

Philip W. Ingham

Genes Dev. 2012, 26:

Access the most recent version at doi:10.1101/gad.207126.112

Related Content Scube/You activity mediates release of dually lipid-modified Hedgehog signal in soluble form

Adrian Creanga, Thomas D. Glenn, Randall K. Mann, et al.

Genes Dev. June , 2012 26: 1312-1325

References This article cites 16 articles, 4 of which can be accessed free at:

http://genesdev.cshlp.org/content/26/22/2468.full.html\#ref-list-1

Articles cited in:

http://genesdev.cshlp.org/content/26/22/2468.full.html\#related-urls

\section{License}

Email Alerting

Receive free email alerts when new articles cite this article - sign up in the box at the top

Service right corner of the article or click here.

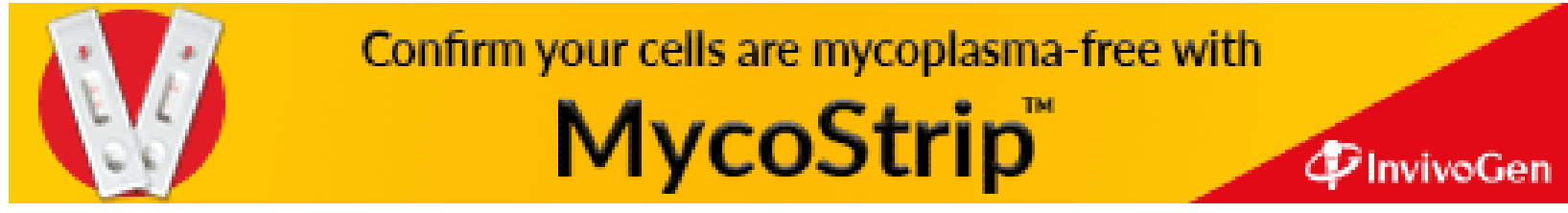

